\title{
Profilul de rezistență la antimicrobiene al tulpinilor de Klebsiella pneumoniae într-o clinică de boli infecțioase
}

\author{
Lucian Giubelan, Livia Dragonu, Andreea Cristina Stoian, \\ Florentina Dumitrescu
}

Clinica de Boli Infecţioase, Universitatea de Medicină şi Farmacie, Craiova, România

\begin{abstract}
REZUMAT
Obiective. Stabilirea profilului de rezistenţă al tulpinilor de Klebsiella pneumoniae (KP) izolate în Clinica de Boli Infecţioase Craiova.

Material şi metodă. Studiu retrospectiv (ianuarie 2017-decembrie 2018); KP au fost identificate cu ajutorul sistemului automat Vitek 2, care a stabilit ulterior sensibilitatea acestora la antimicrobiene (testare uzuală la 17 antibiotice, testare extinsă la alte 9); pentru fiecare tulpină a fost calculat indicele de rezistenţă MAR (limite: 0-1); informaţiile au fost introduse într-o baza de date Excel. Au fost testate 45 de tulpini în 2017 şi 290 în 2018. Procentul de tulpini MDR a fost calculat pe baza definiţiilor internaţional acceptate.

Rezultate. Au fost identificate 335 de tulpini, marea majoritatea izolate prin cultura sputei (192 tulpini $57,31 \%)$. Date demografice: 330 tulpini $(99 \%)$ au fost izolate la subiecţi adulţi, $190(57 \%)$ la pacienţi de sex masculin, $185(55 \%)$ la bolnavi ce trăiesc în mediul urban. Valoarea globală a MAR a fost de 0,37 (faţă de 0,32 pentru ansamblul tulpinilor germenilor Gram negativi izolaţi). Peste $80 \%$ din tulpinile de KP a fost sensibile la Amikacină şi Polimixina E; sensibilităţi între 60 şi $79 \%$ au fost observate pentru Meropenem, Gentamicină, Tobramicină, Ciprofloxacină, Ertapenem, Trimetoprim-Sulfametoxazol, Levofloxacina, Cefepima, iar între 40 şi 59\% pentru Ceftriaxonă, Cefoxitină, Ceftazidimă, Minociclină şi Imipenem. Sub 39\% dintre tulpini sunt sensibile la Ampicilină ( \pm Sulbactam), Piperacilină ( \pm Tazobactam), Ticarcilină ( \pm Acid clavulanic), Aztreonam, Pefloxacină, Cefazolin, Nitrofurantoin. Rezistenţa la principalele clase de antibiotice arată valori mai mici faţă de datele naţionale şi europene pentru cefalosporine de generaţia a 3-a, fluorochinolone şi aminoglicozide, dar un procent mult mai mare de rezistenţă la carbapeneme. Peste $68 \%$ dintre izolate sunt multidrog-rezistente (MDR); peste 60\% dintre tulpini provin din surse în care există un contact important cu substanţele antimicrobiene.

Concluzii. Peste $80 \%$ dintre tulpinile izolate sunt sensibile la Amikacină sau Polimixina E.; peste $29 \%$ dintre tulpini demonstrează rezistenţă la clasa carbapenemelor în 2018; peste 68\% dintre izolate sunt multidrogrezistente; peste $60 \%$ dintre tulpini provin din surse în care există un contact important cu substanţele antimicrobiene.
\end{abstract}

Cuvinte cheie: Klebsiella pneumoniae, rezistenţă la antimicrobiene, MAR

\section{INTRODUCERE}

Klebsiella pneumoniae (KP) este o bacterie Gram negativă (BGN) importantă în patologia umană, generând o paletă largă de infecţii (în principal urinare şi respiratorii, dar şi infecţii sistemice, digestive sau meningeale).

Rezistenţa la substanţele antimicrobiene este o problemă importantă de sănătate publică la nivel global, recunoscută ca atare de către Organizaţia Mondi- ală a Sănătăţii (OMS) [1], care a publicat în 2017 o listă de 12 bacterii pentru care este nevoie urgentă de dezvoltare de noi antibiotice; printre acestea, la prioritatea 1 (necesitate critică) se află enterobacteriaceele (din care face parte şi KP) producătoare de betalactamaze cu spectru extins şi, în special, carbapenemaze [2]. Ultimul raport al Centrul European pentru Prevenţia şi Controlul Bolilor (ECDC) [3], dar şi datele din ţara noastră (vezi studiul CARMIN-ROM [4]) 
aduc date îngrijorătoare în privinţa rezistenţei KP la antibiotice. Bacteria s-a dovedit un germen ,problemă“ încă din 1971, fiind descrise o serie de cazuri cu tulpini rezistente la Gentamicină [5], pentru ca, în anii ' 90 , tulpinile rezistente la cefalosporine să constituie impedimente pentru tratamentul bolnavilor [6], iar în prezent răspândirea tulpinilor producătoare de betalactamaze să capete caracterul unei adevărate epidemii [7-9]. Se poate afirma că KP este una dintre cele mai importante bacterii implicate în infecţiile nosocomiale.

Pentru clinicieni, este importantă cunoaşterea rezistenţei generale la antibiotice a tulpinilor de KP în aria în care aceştia îşi desfăsoară activitatea, pentru un răspuns terapeutic rapid şi adecvat.

\section{OBIECTIVE}

Stabilirea profilului de rezistenţă al tulpinilor de Klebsiella pneumoniae (KP) izolate în Clinica de Boli Infecţioase Craiova (din cadrul Spitalului de Boli Infecţioase şi Pneumoftiziologie „Victor Babeş").

\section{MATERIAL ŞI METODĂ}

Studiu retrospectiv (ianuarie 2017-decembrie 2018) bazat pe datele din registrul laboratorului spitalului; BGN şi, în particular, KP au fost identificate cu ajutorul sistemului automat Vitek 2, care a stabilit ulterior sensibilitatea acestora la antimicrobiene; majoritatea tulpinilor $(317,94,62 \%)$ au fost testate la 17 antibiotice, situaţia exactă fiind prezentată în Figura 1; pentru fiecare tulpină a fost calculat indicele de rezistenţă MAR (limite: 0-1). Au fost testate 45 de tulpini în 2017 şi 290 în 2018. Pentru analiză, a fost alcătuită o bază de date Excel.

\section{REZULTATE}

$\mathrm{Au}$ fost identificate 335 de tulpini (dintr-un total de 1358 de tulpini de BGN, KP fiind a doua cea mai importantă bacterie din acest grup (24,66\%), după Escherichia coli.

\section{Date demografice}

Vârsta mediană a bolnavilor a fost de 64 de ani (cu limite între < 1 an şi 88 ani); 330 tulpini (98,50\%) au fost izolate la subiecţi adulţi, $190(56,71 \%)$ la pacienţi de sex masculin, $185(55,22 \%)$ la bolnavi care trăiesc în mediul urban.

TABEL 1. Tipul şi numărul de probe din care s-a izolat KP

\begin{tabular}{|l|c|}
\hline Produs patologic & Nr. probe \\
\hline Spută & 192 \\
\hline Urocultură & 123 \\
\hline Hemocultură & 6 \\
\hline Secreție plagă & 6 \\
\hline Secreție vaginală & 5 \\
\hline Aspirat bronşic & 3 \\
\hline
\end{tabular}

Marea majoritate a KP au fost izolate din spută (192 tulpini, 57,31\%) sau urocultură (123 tulpini $36,71 \%$ ). O situaţie exactă a produselor patologice din care s-a izolat bacteria este prezentată în tabelul

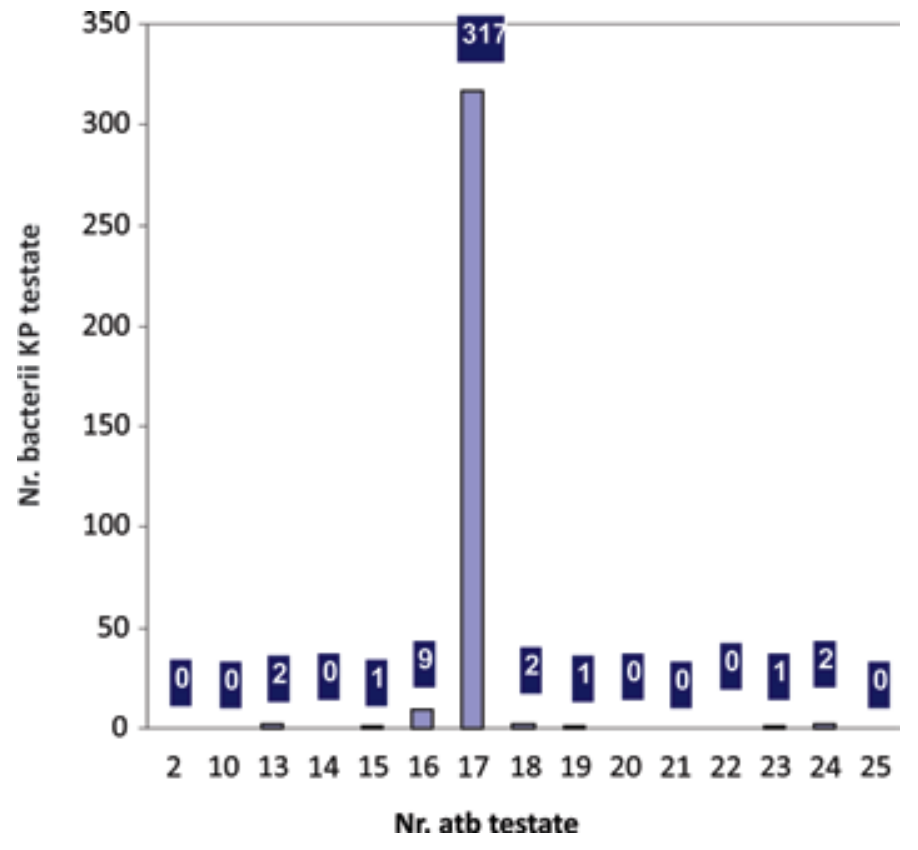

FIGURA 1. Distribuția tulpinilor de KP în funcție de numărul de antibiotice pentru care a fost testată sensibilitatea acestora 
1. De menţionat că, la pacienţii pediatrici, KP nu a fost izolată decât din probe de urină.

Profilul de rezistenţă al KP pentru un anumit antibiotic-test este prezentat în tabelul 2.

Peste $80 \%$ dintre tulpinile de KP au fost sensibile la Amikacină şi Polimixina E; sensibilităţi între 60 şi 79\% au fost observate pentru Meropenem, Gentamicină, Tobramicină, Ciprofloxacină, Ertapenem, Trimetoprim-Sulfametoxazol, Levofloxacina, Cefepima, iar între 40 şi $59 \%$ - pentru Ceftriaxonă, Cefoxitină, Ceftazidimă, Minociclină şi Imipenem-cilastatin. Sub $39 \%$ dintre tulpini sunt sensibile la Ampicilină ( \pm Sulbactam $), \quad$ Piperacilină ( \pm Tazobactam $),$ Ticarcilină ( \pm Acid clavulanic), Aztreonam, Pefloxacină, Cefazolin, Nitrofurantoin. În figura 2 este prezentat grafic profilul de sensibilitate al tulpinilor de KP.

Valoarea globală a MAR a fost de 0,37 (faţă de 0,32 pentru ansamblul tulpinilor germenilor Gram negativi izolaţi). În figura 3 este reprezentată grafic distribuţia tulpinilor de KP în funcţie de valorile fracţiunile MAR.

În tabelul 3 este reflectată variaţia procentului de tulpini de KP rezistente la diferitele clase de antibiotice în doi ani consecutivi (2017 şi 2018).
TABEL 3. Procentul tulpinilor de KP rezistente la diferitele clase de antimicrobiene - 2017 vs. 2018

\begin{tabular}{|c|c|c|c|c|c|}
\hline & AminoP & CEF 3 & FQ & AG & CarbaP \\
\hline & \multicolumn{5}{|c|}{2017} \\
\hline total KP & 45 & 45 & 45 & 45 & 45 \\
\hline $\mathbf{r}$ & 45 & 27 & 13 & 15 & 17 \\
\hline$\%$ & 100 & 60 & 28,89 & 33,33 & 37,78 \\
\hline \multicolumn{5}{|c|}{2018} \\
\hline total KP & 290 & 290 & 290 & 290 & 290 \\
\hline $\mathbf{r}$ & 289 & 134 & 88 & 78 & 85 \\
\hline$\%$ & 99,66 & 46,21 & 30,34 & 26,90 & 29,31 \\
\hline
\end{tabular}

Amino $P$ = aminopeniciline, CEF 3 = cefalosporine de generația $a$ 3- $a$, $F Q=$ fluorochinolone,$A G=$ aminoglicozide, $C a r b a P=$ carbapeneme, $K P=$ Klebsiella pneumoniae, $r=$ (nr. tulpini) rezistente (la antimicrobiene)

\section{DISCUȚII}

Rezistenţa la aminopeniciline a KP în clinica noastră a fost în medie de 99,7\% (100\% în 2017 şi 99,66\% în 2018); rezistenţa la această clasă de antimicrobiene nu mai este, practic, menţionată nici de către raportul ECDC, dar nici de către studiul CARMIN-ROM [3,4]. Cel mai probabil, vom renunţa la acest tip de testare şi în clinica craioveană.

Rezistenţa la cefalosporine de generaţia a 3-a în EU a fost în medie de 31,2-31,7\% la nivelul UE (2017 şi 2018). În 2018, România se situa pe locul 4

TABEL 2. Profilul de rezistență al tulpinilor de KP în funcție de antibioticul testat

\begin{tabular}{|l|c|c|c|c|c|c|}
\hline & $\mathbf{s}$ & $\mathbf{i}$ & $\mathbf{r}$ & $\mathbf{s} \%$ & $\mathbf{i} \%$ & $\mathbf{r} \%$ \\
\hline Amikacina & 286 & 29 & 20 & 85,37 & 8,66 & 5,97 \\
\hline Ampicilina & 6 & 8 & 302 & 1,90 & 2,53 & 95,57 \\
\hline Ampicilina-Sulbactam & 103 & 62 & 148 & 32,91 & 19,81 & 47,28 \\
\hline Aztreonam* & 2 & 6 & 12 & 10,00 & 30,00 & 60,00 \\
\hline Cefazolin & 108 & 0 & 208 & 34,18 & 0,00 & 65,82 \\
\hline Cefepima & 210 & 52 & 70 & 63,25 & 15,66 & 21,08 \\
\hline Cefoxitin & 178 & 10 & 125 & 56,87 & 3,19 & 39,94 \\
\hline Ceftazidim & 183 & 77 & 72 & 55,12 & 23,19 & 21,69 \\
\hline Ceftriaxona & 182 & 56 & 79 & 57,41 & 17,67 & 24,92 \\
\hline Ciprofloxacina & 244 & 2 & 89 & 72,84 & 0,60 & 26,57 \\
\hline Ertapenem & 227 & 21 & 66 & 72,29 & 6,69 & 21,02 \\
\hline Gentamicina & 254 & 7 & 74 & 75,82 & 2,09 & 22,09 \\
\hline Imipenem* & 9 & 1 & 11 & 42,86 & 4,76 & 52,38 \\
\hline Levofloxacina & 239 & 7 & 88 & 71,56 & 2,10 & 26,35 \\
\hline Meropenem & 267 & 18 & 49 & 79,94 & 5,39 & 14,67 \\
\hline Minociclina* & 11 & 2 & 8 & 52,38 & 9,52 & 38,10 \\
\hline Nitrofurantoin & 63 & 105 & 145 & 20,13 & 33,55 & 46,33 \\
\hline Pefloxacina* & 5 & 1 & 15 & 23,81 & 4,76 & 71,43 \\
\hline Piperacilina & 29 & 6 & 298 & 8,71 & 1,80 & 89,49 \\
\hline Piperacilina-Tazobactam* & 4 & 6 & 12 & 18,18 & 27,27 & 54,55 \\
\hline Polimixina E* & 23 & 0 & 3 & 88,46 & 0,00 & 11,54 \\
\hline Ticarcilina* & 0 & 0 & 20 & 0,00 & 0,00 & 100,00 \\
\hline Ticarcilina-Acid clavulanic* & 0 & 8 & 1 & 0,00 & 88,89 & 11,11 \\
\hline Tobramicina & 250 & 13 & 72 & 74,63 & 3,88 & 21,49 \\
\hline Trimetoprim-Sulfametoxazol & 238 & 0 & 94 & 71,69 & 0,00 & 28,31 \\
\hline
\end{tabular}




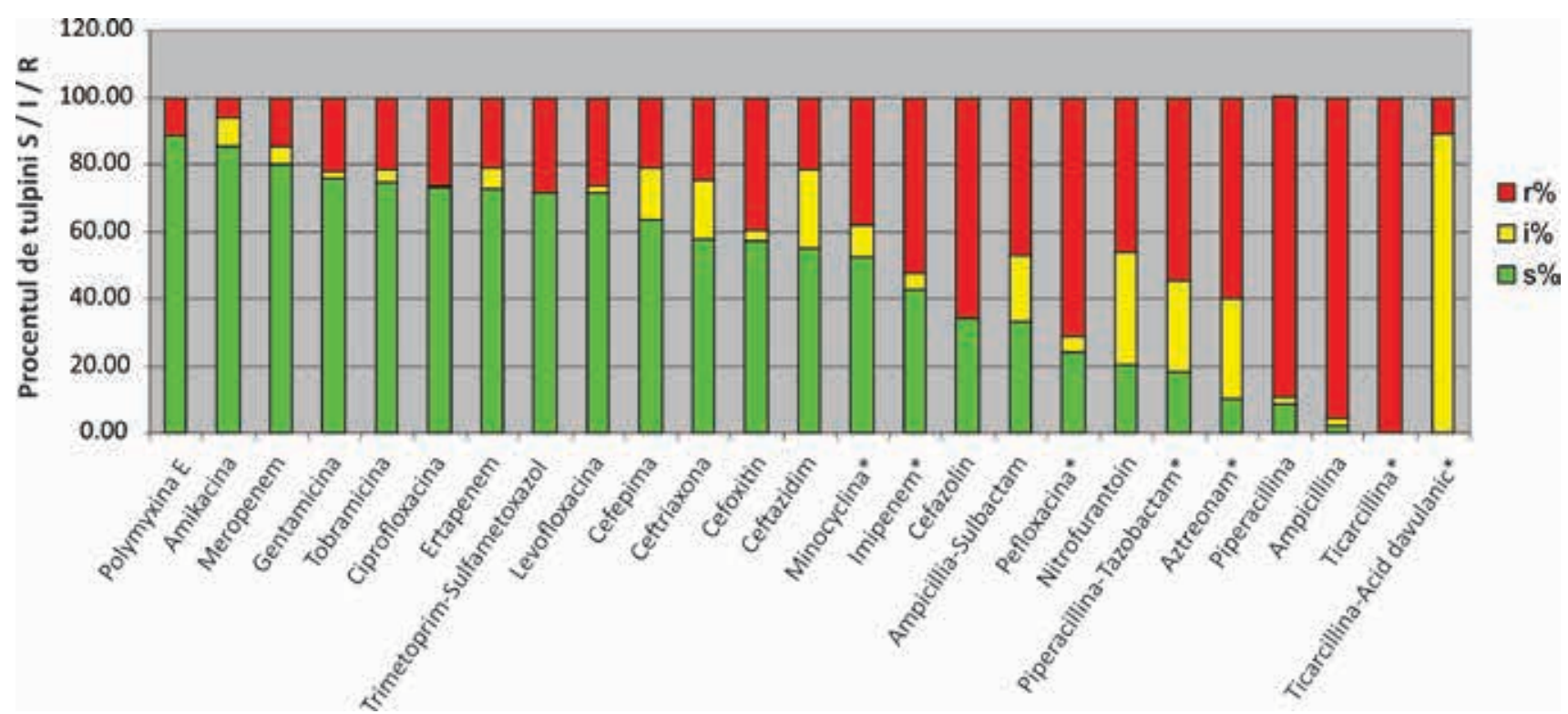

FIGURA 2. Profilul de sensibilitate la antibiotice a tulpinilor de KP izolate. Legenda: $S=$ sensibil (verde), I= intermediar sensibil, sensibil în funcție de doză (galben), $R$ = rezistent (roşu)

\section{MAR Klebsiella pneumoniae}

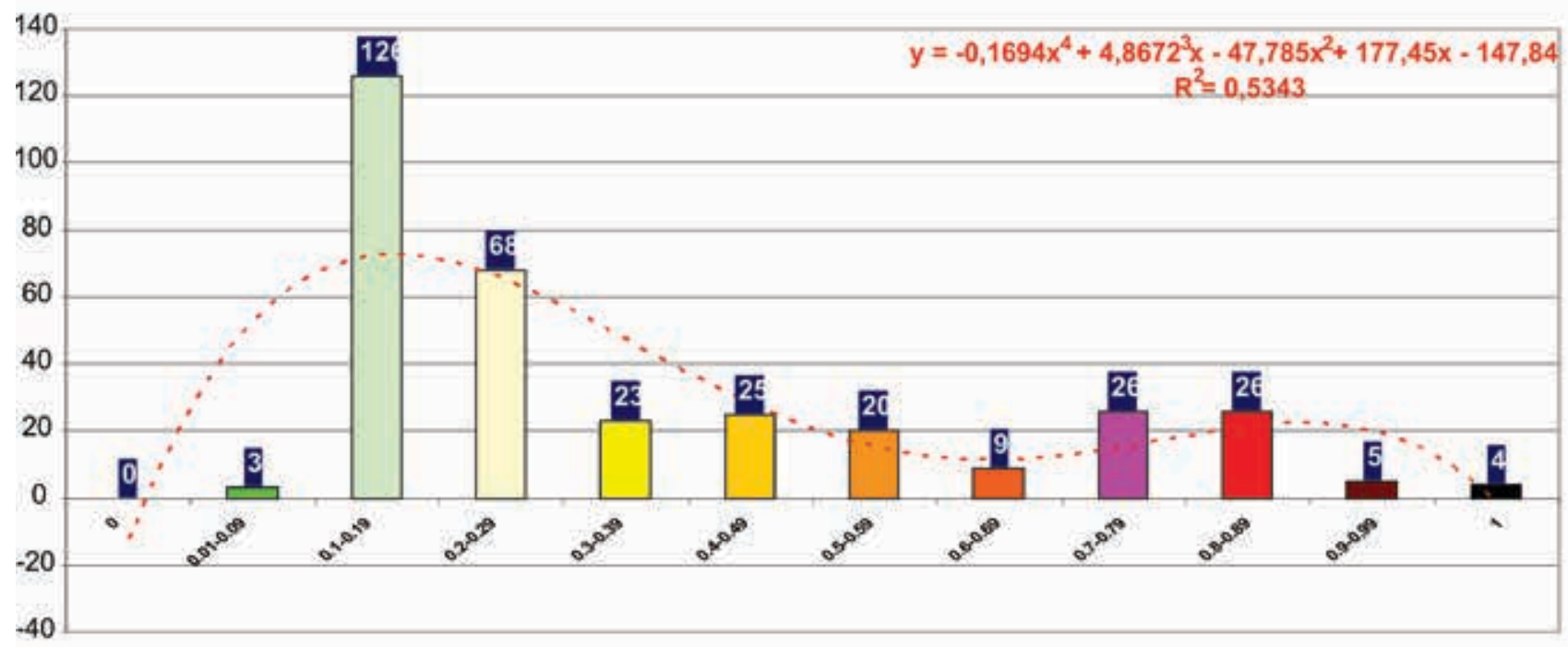

FIGURA 3. Distribuția tulpinilor de KP în funcție de valorile fracțiunile MAR

la nivel european, cu o valoare procentuală medie de $61,4 \%$, cu puţin sub valoarea înregistrată în 2017 (62,5\% - ECDC [3], respectiv 63,4\% - CARMIN [4]). Datele noastre arată o rezistenţă de $60 \%$ în 2017 , respectiv 46,21\% în 2018 (semnificativ mai mică decât valorile prezentate anterior).

Rezistenţa la fluorochinolone a KP în România este de 1,5-2 ori peste valorile medii europene (31,531,6\% în 2017 şi 2018 [3]), fiind de 64,1\% în 2017 (66,5\% conform CARMIN-ROM [4]), în uşoară scădere în 2018, până la valoarea de 57,4\%. La nivelul clinicii noastre, situaţia este însă mult diferită, rezis- tenţa la Ciprofloxacin şi Levofloxacin fiind în medie de 30,15\% (28,89 în 2017, respectiv 30,34\% în 2018, când a fost testat un număr semnificativ mai mare de tulpini).

În ceea ce priveşte rezistenţa la aminoglicozide, nivelul mediu european a fost de 22,7-24,1\% în doi ani consecutivi, 2017 şi 2018, România ocupând locul 5, cu o valoare procentuală de 58,6 în 2017, în scădere la 50,9 pentru 2018; procentul din 2017 este confirmat şi de către studiul multicentric românesc $[3,4]$. Datele obţinute de către noi arată o valoare procentuală de $33,3 \%$ în 2017 , în scădere la $26,9 \%$ în 
2018 (dar pe baza unui număr de testări de peste 6 ori mai mare), valori regionale mult diferite faţă de cele înregistrate la nivel naţional sau european. Cea mai mică rezistenţă a KP a fost înregistrată pentru Amikacină (de aproape 4 ori mai mică decât pentru Gentamicină sau Tobramicină). O situaţie similară am înregistrat pentru tulpinile de Escherichia coli [10].

Pentru anul 2018, procentul de rezistenţă al KP la carbapeneme în UE este de7,5\%, în uşoară creştere faţă de 2017 - 7,2\% [3]. România ocupă locul 3, cu un procent de aproape 4 ori mai mare faţă de datele europene (29,5\% în 2018), de asemenea, în creştere faţă de 2017 - 22,5\%. Studiul CARMIN-ROM confirmă datele pentru 2017, identificând un procent de 22,5\% tulpini KP rezistente la carbapeneme [4]. Datele noastre arată, similar cu ceea ce am constatat pentru tulpinile de EC [10], un procent de rezistenţă la Meropenem, Ertapenem sau la ambele de 37,79\% în 2017, respectiv 29,31\% în 2018. Ca urmare a numărului mic de tulpini testate, nu am luat în considerare datele pentru Imipenem-Cilastatin.

$\mathrm{Au}$ fost descrise tulpini rezistente la polimixine, majoritatea în cadrul unor infecţii sistemice sau diagnosticate la gazde speciale, cu impact important în ceea ce priveşte mortalitatea cazurilor [11-14]. Studiul CARMIN-ROM a identificat un procent de 55,8\% tulpini de KP rezistente la Colistin dintre izolatele deja rezistente la carbapeneme; în schimb, dintre tulpinile sensibile la carbapeneme, doar 5 din 104 tulpini $(4,8 \%)$ au demonstrat şi rezistenţă la polimixi-

Conflict of interest: none declared

Financial support: none declared

\section{BIBLIOGRAFIE}

1. WHO. 2015 Global action plan on antimicrobial resistance, available at: https://www.who.int/antimicrobial-resistance/publications/ global-action-plan/en/.

2. WHO. $2017 \mathrm{WHO}$ publishes list of bacteria for which new antibiotics are urgently needed, available at: https://www.who.int/news-room/ detail/27-02-2017-who-publishes-list-of-bacteria-for-which-newantibiotics-are-urgently-needed.

3. ECDC. 2019 Surveillance of antimicrobial resistance in Europe 2018, available at: https://www.ecdc.europa.eu/sites/default/files/ documents/surveillance-antimicrobial-resistance-Europe-2018.pdf.

4. Popescu GA., Şerban R., Niculcea A. 2019 CARMIN-ROM 2017 (Consumul de antibiotice, rezistenţa microbiană şi infecțiile asociate asistenţei medicale (nosocomiale) în România - 2017):44-49. Available at: https://www.cnscbt.ro/index.php/analiza-datesupraveghere/infectii-nosocomiale-1/1309-consumul-de-antibioticerezistenta-microbiana-si-infectii-asociate-asistentei-medicalenosocomiale-in-romania-2017/file.

5. Martin CM., Ikari NS., Zimmerman J., Naitz JA. A virulent nosocomial Klebsiella with a transferable R factor for Gentamicin: emergence and supression, J Infect Dis. 1971;124(suppl):s24-s29.

6. Pena $\mathrm{C}$, Pujol M, Ardanuy $\mathrm{C}$ et al. Epidemiology and successful control of a large outbreak due to Klebsiella pneumoniae producing ne [4]. În clinica noastră, trei tulpini au fost rezistente la Colistin $(0,89 \%$ din totalul tulpinilor), din 23 izolate testate.

În conformitate cu criteriile de definiţie pentru multirezistenţă (MDR) şi rezistenţă extinsă la antimicrobiene (XDR) [15], am identificat 68,86\% dintre tulpinile KP ca fiind MDR, dar nu am înregistrat nicio tulpină XDR.

Având în vedere criteriile lui Krumperman [16], am identificat 206 tulpini KP $(61,49 \%)$ cu un indice MAR de peste 0,2 , ceea ce sugerează că majoritatea tulpinilor analizate provin din surse cu expunere importantă la antibiotice (cel mai probabil intraspitaliceşti).

\section{CONCLUZII}

Peste $80 \%$ dintre tulpinile izolate sunt sensibile la Amikacină sau Polimixina E; faţă de datele naţionale sau cele europene cu referire la ţara noastră, datele din clinica craioveană arată procentaje mai mici de rezistenţă la clasa cefalosporinelor de generaţia a 3-a, fluorochinolone sau aminoglicozide, dar mult mai mari pentru carbapeneme; peste $29 \%$ dintre tulpini demonstrează rezistenţă la clasa carbapenemelor în 2018; peste $68 \%$ dintre izolate sunt multidrog-rezistente; peste $60 \%$ dintre tulpini provin din surse în care există un contact important cu substanţele antimicrobiene. extended-spectrum betalactamases. Antimicrob Agents Chemother. 1998;42(1):53-58.

7. David S, Reuter S, Harris SR et al. Epidemic of carbapenemresistant Klebsiella pneumoniae in Europe is driven by nosocomial spread. Nat Microbiol. 2019;4:1919-1929.

8. Jin C, Shi R, Jiang X et al. Epidemic characteristics of carbapenemresistant Klebsiella pneumoniae in the pediatric intensive care unit of Yanbian University Hospital, China. Infect Drug Resist. 2020; 13:1439-1446.

9. Rojas LJ, Weinstack GM, De La Cadena E et al. An analysis of the epidemic of Klebsiella pneumoniae carbapenemase-producing Klebsiella pneumoniae: convergence of two evolutionary mechanisms creates the "perfect storm". J Infect Dis. 2018; 217(1):82-92

10. Giubelan L, Diaconescu I, Dragonu L et al. Profilul de rezistenţă la antimicrobiene al tulpinilor de Escherichia coli într-o clinică de boli infecţioase. Ro J Infect Dis. 2020;23(3):224-228.

11. Capone A, Gianella M, Fortini D et al. High rate of colistin resistance among patients with carbapenem-resistant Klebsiella pneumoniae infection accounts for an excess of mortality. Clin Microbiol Inf. 2013;19(1):e23-e30. 
12. Emergence of colistin resistance in multidrug-resistant Klebsiella pneumoniae and Escherichia coli strains isolates from cancer patients. Ann Clin Microbiol Antimicrob. 2019;18:40.

13. Menekese S, Cag Y, Isik ME et al. The effect of colistin resistance and other predictors on fatality among patients with bloodstream infection due to Klebsiella pneumoniae in an OXA-48 dominant region. Int J Inf Dis. 2019;86:208-211.

14. El-Sayed Ahmed MAEG, Zhang LL, Shen $C$ et al. Colistin and its role in the era of antibiotic resistance: an extended review (2000-2019). Emerg Microbes Infect. 2020;9(1):868-885.
15. Magiorakos AP, Srinivasan A, Carey RB et al. Multidrug-resistant, extensively drug-resistant and pandrug-resistant bacteria: an international expert proposal for interim standard definitions for acquired resistance. Clin Microbiol Infect. 2012;18:268-281.

16. Krumperman $\mathrm{PH}$. Multiple antibiotic resistance indexing of Escherichia coli to identify high-risk sources of fecal contamination of foods. Appl Environ Microbiol. 1983;46(1):165-170. 